\title{
Effects of Maternal Anemia on Neonatal Outcome
}

\author{
Adhikari $\mathrm{J}^{1}$, Belbase $\mathrm{M}^{2}$, Rijal $\mathrm{S}^{3}$
}

\begin{abstract}
Introduction: Anemia is one of the most prevalent nutritional deficiency problem affecting pregnant women. It is defined by World Health Organization as hemoglobin $(\mathrm{Hb})$ level of less than $11 \mathrm{~g} / \mathrm{dl}$. Hemoglobin level of 9.0- $10.9 \mathrm{~g} / \mathrm{dl}$ is mild, 7.0-8.9 g/dl is moderate and less than $7 \mathrm{~g} / \mathrm{dl}$ is severe anemia respectively. Maternal anemia in pregnancy is commonly considered as a risk factor for poor pregnancy outcome and can result in complications that threaten the life of both mother and fetus. Aims: To find out neonatal outcome delivered to anemic mothers. Methods: A prospective case control study was carried out among 75 newborns delivered to pregnant women with hemoglobin below $10.9 \mathrm{~g} / \mathrm{dL}$. Another 75 newborns were taken delivered at the same time, matched age and sex wise as a control group to mothers whose hemoglobin was more than $11 \mathrm{~g} / \mathrm{dl}$. Results: Out of total 75 cases $35(46.7 \%)$ mothers had mild, 32(42.6\%) had moderate and $8(10.7 \%)$ had severe anemia respectively. Similarly, the risk of having preterm baby among anemia group was 4.42 times higher than that in control group ( $p$ 0.033). The risk of having low birth weight in anemia group was 3.9 times higher than that in control group ( $p$ 0.04). The mean of head circumference (HC) among the anemia group was $33.9 \mathrm{~cm} \pm 1.40$ (Mean \pm SD) and among the control group was $34.4 \mathrm{~cm} \pm 1.24$ (Mean $\pm S D$ ) with a mean difference of $0.5 \mathrm{~cm}$ (p 0.032). The mean of length among anemia group was $45.3 \mathrm{~cm} \pm 1.97$ (Mean $\pm S D$ ) and among the control group was $46.2 \mathrm{~cm} \pm 1.69$ $(M e a n \pm S D$ ) with a mean difference of $0.9 \mathrm{~cm}$ ( $p$ 0.003). Conclusion: Maternal anemia in pregnancy is associated with increased risk of adverse neonatal outcome. Efforts must be made to reduce the prevalence of anemia especially during pregnancy to reduce neonatal morbidity and mortality.
\end{abstract}

Keywords: Anemia, Low birth weight, Neonates, Prematurity

\section{Author:}

1. Dr. Jyoti Adhikari

2. Dr. Mohan Belbase

3. Dr. Shikha Rijal

${ }^{1}$ Department of Pediatrics, Nepalgunj Medical College and Teaching Hospital, Kohalpur, Banke

${ }^{2}$ Department of Psychiatry, Nepalgunj Medical College and Teaching Hospital, Kohalpur, Banke

${ }^{3}$ Department of Pediatrics

\section{Address for Correspondence:}

Dr. Jyoti Adhikari

Assistant Professor

Department of Pediatrics

Nepalgunj Medical College and Teaching Hospital

Kohalpur, Banke

Email: adhikarijyoti@yahoo.com

\section{INTRODUCTION}

Anemia is one of the most prevalent nutritional deficiency problem affecting pregnant women. It is defined by WHO as hemoglobin $(\mathrm{Hb})$ levels of less than $11 \mathrm{~g} / \mathrm{dL} .{ }^{1}$ Hemoglobin level of $9.0-10.9 \mathrm{~g} / \mathrm{dL}$ is mild, $7.0-8.9 \mathrm{~g} / \mathrm{dL}$ is moderate and less than $7 \mathrm{~g} / \mathrm{dL}$ is severe anemia respectively. ${ }^{2} \mathrm{CDC}$ recommends that hemoglobin in pregnant women should not be allowed to fall below $10.5 \mathrm{gm} / \mathrm{dl}$ in second trimester, taking into account the physiological changes in pregnancy. ${ }^{1}$

The fall in hemoglobin concentration during pregnancy is due to combined effects of hemodilution and negative iron balance. ${ }^{3}$ Anemia affects nearly half of all pregnant women in the world: $52 \%$ in developing countries compared with $23 \%$ in the developed world. In Asia, the prevalence of anemia was estimated to be $44 \%$ in non-pregnant and $60 \%$ in pregnant women. ${ }^{4}$ Maternal anemia in pregnancy is commonly considered as a risk factor for poor pregnancy outcome and can result in complications that threaten the life of both mother and fetus. Current knowledge indicates that anemia in pregnancy is a risk factor for preterm delivery, subsequent low birth weight (LBW) and possible inferior neonatal health. ${ }^{5}$

Anemia begins in childhood, worsens during adolescence in girls and gets aggravated during pregnancy. The majority of women in the developing countries start pregnancy with depleted body stores of these nutrients and this means that their extra requirement is even higher than usual. ${ }^{6}$ Thus, by better understanding of the effects of maternal anemia on neonatal outcome we can decrease neonatal mortality and morbidity. 


\section{METHODS}

A prospective case control study was carried out after obtaining ethical approval from IRC NGMC among 75 newborns in the department of pediatrics, delivered to pregnant women with $\mathrm{Hb}$ level below $10.9 \mathrm{~g} / \mathrm{dL}$ over the period of one year from March 2019 to February 2020. Another 75 newborns were taken delivered at the same time, matched age and sex wise as a control group to mothers whose $\mathrm{Hb}$ level was more than $11 \mathrm{~g} /$ $\mathrm{dL}$. All newborns whose mothers were willing to participate and delivered in NGMCTH were included in the study whereas those mothers not willing to participate, delivered outside NGMCTH and pregnant women having chronic medical illness, twin pregnancy, previous history of preterm delivery were excluded from the study. Anemic and non-anemic mothers were matched by parity and babies delivered on the same day were taken. Every mother was interviewed personally in Nepalese language. Neonatal outcome were measured in terms of prematurity, birth weight, and anthropometric indices and compared between cases and control. Data taken was processed and analyzed by using Statistical Package for Social Sciences (SPSS 20). Variables were expressed in the form of frequencies and percentage. Descriptive studies such as mean, standard deviation, Odd Ratio were computed. Chi square test and t-test was done to analyze relationship between risk factors. The study was aimed to find out neonatal outcome delivered to anemic mothers.

\section{RESULTS}

Out of the total 75 cases $35(46.7 \%)$ mothers had mild anemia, $32(42.6 \%)$ had moderate anemia and $8(10.7 \%)$ had severe anemia.

\begin{tabular}{|c|c|c|c|c|c|}
\hline $\begin{array}{l}\text { Weeks of } \\
\text { gestation }\end{array}$ & $\begin{array}{l}\text { Case } \\
(\%)\end{array}$ & $\begin{array}{c}\text { Control } \\
\text { (\%) }\end{array}$ & Total & OR(95\% Cl) & $p$ value \\
\hline$<37$ & $\begin{array}{c}18 \\
(24 \%)\end{array}$ & $\begin{array}{c}5 \\
(6 \%)\end{array}$ & 23 & \multirow{3}{*}{$\begin{array}{c}4.42 \\
(1.4610 .43)\end{array}$} & \multirow{3}{*}{0.033} \\
\hline$>37$ & $\begin{array}{c}57 \\
(76 \%)\end{array}$ & $\begin{array}{c}70 \\
(94 \%)\end{array}$ & 127 & & \\
\hline Total & $\begin{array}{c}75 \\
(100 \%)\end{array}$ & $\begin{array}{c}75 \\
(100 \%)\end{array}$ & 150 & & \\
\hline
\end{tabular}

Table I: Preterm babies among case and control

There were $18(24 \%)$ preterm babies in anemia group in comparison to $5(6 \%)$ in control group. The risk of having preterm babies was 4.42 times higher in anemia group with a statistical significance (Table I)

\begin{tabular}{|c|c|c|c|c|c|}
\hline Birth weight & $\begin{array}{c}\text { Case } \\
\text { (\%) }\end{array}$ & $\begin{array}{c}\text { Control } \\
\text { (\%) }\end{array}$ & Total & OR(95\% Cl) & $p$ value \\
\hline$<2500 \mathrm{Kg}$ & $\begin{array}{c}19 \\
(25 \%)\end{array}$ & $\begin{array}{c}6 \\
(8 \%)\end{array}$ & 25 & \multirow{3}{*}{$\begin{array}{c}3.9 \\
(1.46-10.43)\end{array}$} & \multirow{3}{*}{0.04} \\
\hline$>2500 \mathrm{Kg}$ & $\begin{array}{c}56 \\
(75 \%)\end{array}$ & $\begin{array}{c}69 \\
(92 \%)\end{array}$ & 125 & & \\
\hline Total & $\begin{array}{c}75 \\
(100 \%)\end{array}$ & $\begin{array}{c}75 \\
(100 \%)\end{array}$ & 150 & & \\
\hline
\end{tabular}

Table II: Low Birth weight among case and control

Among 75 cases, 19(25\%) were LBW in anemia group and $6(8 \%)$ were LBW in control group. The risk of having LBW was 3.9 times higher in anemia group than that in control group which is statistically significant (Table II)

\begin{tabular}{lccc} 
& Mean $\mathrm{HC}(\mathrm{cm})$ & Std Deviation & p value \\
Case & 33.9 & 1.404 & \\
\hline Control & 34.4 & 1.246 & $0.032^{*}$ \\
\hline
\end{tabular}

Table III: Comparison of HC among cases and control

The mean $\mathrm{HC}$ in anemia group was $33.9 \pm 1.40$ (Mean \pm SD) $\mathrm{cm}$ whereas it was $34.4 \pm 1.24(\mathrm{M} \pm \mathrm{SD}) \mathrm{cm}$ in the control group. The difference of the two means was statistically significant (Table III).

\begin{tabular}{cccc|} 
& Mean Length $(\mathbf{c m})$ & Std Deviation & P value \\
\hline Case & 45.3 & 2.22 & \\
\hline Control & 46.2 & 1.69 & $0.003^{*}$ \\
\hline * test & & & \\
\hline
\end{tabular}

Table IV: Comparison of length among case and control

The mean length among anemia group was $45.3 \pm 2.2$ (Mean \pm SD) as compared to the control group $46.2 \pm 1.69$ (Mean \pm SD). The difference of the two means was statistically significant (table IV).

\section{DISCUSSION}

In this study, majority of mothers had mild and moderate anemia $90 \%(67)$ and severe anemia was seen in $10 \%(8)$. Similar result was seen in a study conducted in India which documented $6.9 \%$ of anemic mothers had severe anemia. ${ }^{7}$ Various studies have documented less than 5\% anemic mothers had severe anaemia. ${ }^{8,9}$ This could be because of poor nutritional status of adolescence girls, low socioeconomic status, inadequate ANC visits, malaria endemic region, intestinal parasitosis and increased prevalence of hemolytic anemia in the ethnic group 
residing here. Among 75 cases $18(24 \%)$ were preterm and $5(6 \%)$ were preterm among control group. The risk of having a preterm baby in case group was 4.42 times higher than that in control group $(p=0.03)$. In cohort study conducted by Lone et al, the risk of preterm deliveries among anemic group was 4 times higher than that non anemic group which is similar to our study..$^{10}$ Another studies also showed similar results with risk of preterm deliveries. ${ }^{11,12}$ All the above mentioned studies substantiate our study indicating that anemia has poor perinatal outcome with respect to prematurity which could be because maternal anemia induces a stress response and there is increased release of cortisol and other chemical mediators which increases the risk of preterm delivery. ${ }^{13}$

In this study $19(25 \%)$ newborns were LBW in the case and $6(8 \%)$ were LBW in the control group. The risk of LBW was 3.9 times higher in anemic mothers than in the control $(p=0.04)$. Similar observations were reported in various studies. ${ }^{14,15}$ Lone et al, in their study showed that the risk of low birth weight babies in the anemic group was 2.2 times higher than in the non-anemic group, which is slightly lower than that seen in our study. ${ }^{10}$ The increased incidence of LBW in the present study could be due to low nutritional status, low income, illiteracy and poor antenatal care, as also mentioned by other studies. ${ }^{16}$, 17

In our study the mean of $\mathrm{HC}$ among the case group was $33.9 \mathrm{~cm} \pm 1.40(\mathrm{M} \pm \mathrm{SD})$ and among the control group was $34.4 \mathrm{~cm} \pm 1.24(\mathrm{M} \pm \mathrm{SD}$ ) with a mean difference of $0.5 \mathrm{~cm}$ ( $p$ value 0.032 ). The mean of length among the case was $45.3 \mathrm{~cm} \pm 1.97$ $(\mathrm{M} \pm \mathrm{SD})$ and among the control group was $46.2 \mathrm{~cm} \pm 1.69(\mathrm{M} \pm$ SD) with a mean difference of $0.9 \mathrm{~cm}$ ( $p$ value 0.003 ) among the case and control group which is comparable to other studies. 8,18

All the above mentioned studies substantiate our study indicating that anemia has poor preinatal outcome with respect to the anthropometric measurements which could be because the fetal hypothalamic-pituitary-adrenal axis is highly responsive to stress, which leads to increased release of glucocorticoid as a central adaptive mechanism. The glucocorticoid causes the catabolism of fat, glycogen and protein and chronically elevated glucocorticoid concentrations can lead to impaired tissue growth, impaired linear growth and muscle atrophy. ${ }^{19}$

\section{LIMITATIONS}

Small sample size, single center study, unable to randomize the samples is some of the limitations of this study.

\section{CONCLUSION}

The study shows effects of maternal anemia on neonatal outcome and compares the outcome with neonates born to non-anemic mothers during the study period. It was found that more than $2 / 3^{\text {rd }}$ of pregnant mothers suffered from mild to moderate anemia and less had $1 / 3^{\text {rd }}$ had severe anemia. The risk of having preterm and LBW was 4.4 and 3.9 times higher respectively in the case as compared to the control group. Similarly significant differences were observed in anthropometric measurements as well.

\section{REFERENCES}

1. Centers for Disease Control and Prevention. Recommendations to prevent and Control iron deficiency in United States.1998;47:1-36.

2. Stratton JA, Miller RD, Schmidt P. Effect of maternal parasitic disease on the neonate. American J Reproduction Immunology Microbiology 1985;8:141-2.

3. Dutta D.C Physiological changes during pregnancy: In Dutta.D.C. Text book of Obstetrics. $6^{\text {th }}$ edition. Kolkota: New Central Book Agency Pvt Ltd; 2004 p.46-56

4. Rush D. Nutrition and maternal mortality in the developing world. Am J Clinical Nutrition 2000;72 (Suppl):212S-40S.

5. AbouZahr C, Royston E. Maternal mortality. A global fact book. WHO, Geneva 1991;8 : 598 .

6. P.U.Okeke. Anaemia in pregnancy is it a persisting public health problem in Porto novo-cape Verde? Research Journal of Medical Sciences. 2011;5(4):193

7. Malhotra M, Sharma JB, Batra S, Sharma S, Murthy NS, Arora R. Maternal and Perinatal outcome in varying degrees of anaemia. International J Gynecology Obstetrics 2002;79:93100

8. Mehta S. Effects of maternal hemoglobin during pregnancy upon newborns birth weight measurments. Eur jour of pharmaceutical and medical research ejpmr.2015;2(4):973-9

9. Marti-Carvajal A, Pena-Marti G, Comunian G, Munoz S. Prevalence of anemia during pregnancy: results of Valencia (Venezuela) anemia during pregnancy study. Arch Latinoam Nutr 2002; 52: 5-11

10. Lone FW, Qureshi RN, Emanuel F. maternal anaemia prenatal outcome in a tertiary care hospital in Pakistan. Eastern Mediterranean Health Journal. 2004; 10(6):801-7

11. Umber Jalil Bakhtiar, Yasmeen Khan, Razia Nasar.Relationship between maternal hemoglobin and Perinatal outcome RMJ. 2007; 32(2): 102-4

12. Ali AAA, Rayis DA, AbdallahTM, Elbashir MI, Adam I. Severe anaemia is associated with a higher risk for preeclampsia and poor perinatal outcomes in Kassala hospital, eastern Sudan.BMC Research Notes 2011; 4:311-3 .

13. Viteri FE. The consequences of iron deficiency and anemia in pregnancy. Adv. Exp. Med. Biol.1994; 352:127-39.

14. Haggaz AD, Radi EA, Adam I: Anaemia and low birth weight in western Sudan. Trans R Soc Trop Med Hyg 2010; 104:2346.

15. Adam I, Babiker S, Mohmmed AA, Salih MM, Prins $M$ Zaki ZM: Low body massindex, anaemia and poor perinatal outcome in a rural hospital in eastern Sudan. J Trop Pediatr 2008;54:202-4. 
16. Ahuja N, Khanna SD; Influence of maternal factors on the birth weight of full term newborn baby. J Obst Gynec of India.1974;24:131-7.

17. Fischer ES, Lo Gerfo JP, Daling JR; Prenatal care and pregnancy outcomes during the recessions: the Washington state experience. Am J Public Health, 1985; 75(8): 866-69.

18. Ali SM, Murad AM. Effect of Maternal Hemoglobin on Anthropometric Measurements of Full Term Newly Born Babies Iraq J Med Sci, 2013;11(2):170-80

19. Lindsay $\mathrm{H}$. Allen biological effects that might underlie iron effects on fetal growth and pretermJ. Nutr.2001;131(2):5819 